\title{
Minimizing the Level of Butyric Acid Bacteria Spores in Farm Tank Milk
}

\author{
M. M. M. Vissers, ${ }^{* 1}$ F. Driehuis, ${ }^{*}$ M. C. Te Giffel, ${ }^{\star}$ P. De Jong, $†$ and J. M. G. Lankveld‡ \\ *Department of Health and Safety, and \\ †Department of Processing, NIZO Food Research, PO Box 20, 6710 BA Ede, the Netherlands \\ $\ddagger$ Chair of Dairy Science, Wageningen University and Research Centre, PO Box 8129, 6700 EV Wageningen, the Netherlands
}

\begin{abstract}
A year-long survey of 24 dairy farms was conducted to determine the effects of farm management on the concentrations of butyric acid bacteria (BAB) spores in farm tank milk (FTM). The results were used to validate a control strategy derived from model simulations. The $\mathrm{BAB}$ spore concentrations were measured in samples of FTM, feces, bedding material, mixed corn and grass silage fed to cows in the barn, and soil. In addition, a questionnaire was used to gather farm management information such as bedding material used and teat cleaning method applied. The average BAB spore concentration in FTM was $2.7 \log _{10}$ spores/L, and $33 \%$ of the FTM samples exceeded a concentration of $3 \log _{10}$ spores/L. Control of the average spore concentration in mixed silage fed was the only aspect of farm management that was significantly related to the concentration of BAB spores in FTM. Farms that fed mixed silage with the lowest average $\mathrm{BAB}$ spore concentrations (3.4 $\log _{10}$ spores/g) produced FTM with the lowest average concentration (2.1 $\log _{10}$ spores/L). The efficiency of farm management in controlling the $\mathrm{BAB}$ spore concentration in FTM depended to a large extent on the ability of farmers to prevent incidents with elevated BAB spore concentrations in mixed silage ( $>5 \log _{10}$ spores/g) and not on the average BAB spore concentration in mixed silage across the year. The survey showed that farmers should aim for a concentration in mixed silage of less than $3 \log _{10}$ spores/g and should prevent the concentration from exceeding $5 \log _{10}$ spores/g to ensure a concentration in FTM of less than $3 \log _{10}$ spores/L. These results correspond with the previously reported model simulations.
\end{abstract}

Key words: butyric acid bacteria, bulk tank milk, silage, late-blowing

\section{INTRODUCTION}

In semihard cheeses such as Gouda and Emmental, growth of spore-forming anaerobic bacteria, called bu-

Received November 30, 2006.

Accepted March 12, 2007.

${ }^{1}$ Corresponding author: marc.vissers@nizo.nl tyric acid bacteria (BAB), can lead to off-flavors and excessive gas formation, a defect known as late-blowing (Klijn et al., 1995). The BAB are able to convert lactic acid into butyric acid, hydrogen, and carbon dioxide at relatively low $\mathrm{pH}$. In particular, Clostridium tyrobutyricum is associated with the late-blowing defect. Without preventive measures, concentrations in pasteurized cheese milk of more than $1 \log _{10} \mathrm{BAB}$ spores/L can already lead to late-blowing of Gouda-type cheeses (Stadhouders, 1990). Vegetative BAB in farm tank milk (FTM) do not impose risks for Gouda type cheeses, because vegetative cells are inactivated during pasteurization.

To prevent late-blowing, cheese manufacturers have 3 main options: 1) minimizing $\mathrm{BAB}$ spore concentrations in raw milk; 2) removing $\mathrm{BAB}$ spores from raw milk via bactofugation; and 3) preventing the growth of $\mathrm{BAB}$ in cheese by adding inhibitory agents, such as nitrate and lysozyme, to cheese milk (Stadhouders 1990; Waes et al., 1990). In the Netherlands, farmers are encouraged to produce FTM with low concentrations of BAB spores via the milk quality payment systems. Two 0.1-mL tubes of FTM are tested monthly for the presence of $\mathrm{BAB}$ spores. If both tubes test positive, the farmer receives a deduction from the milk price. The Dutch dairy industry wants farmers to produce FTM with a maximum spore limit (MSL) of $3 \log _{10}$ spores/L to obtain (after bactofugation) fewer than 1 $\log _{10}$ spores/L in pasteurized cheese milk.

The BAB spores in FTM originate from the farm environment. Grass and corn silage are the most important sources of BAB spores. Grass and corn silage are fed to cows together (referred to as mixed silage). The BAB spores in the mixed silage accumulate in feces (Te Giffel, 2002). Via the exterior of the cow's teats, feces and $\mathrm{BAB}$ spores are transmitted to milk during milking (Bergère et al., 1968).

Using model simulations, we defined a strategy to achieve a BAB spore concentration in FTM below the MSL. Control of the spore concentration in the mixed silage offered to the cows was shown to be the most important control strategy (Vissers et al., 2006). The model showed that the $\mathrm{BAB}$ spore concentration in 
mixed silage should ideally be less than $3 \log _{10}$ spores/ $\mathrm{g}$ and should not exceed $5 \log _{10}$ spores/g. If the mixed silage contains more than $5 \log _{10}$ spores $/ g$, it is not possible to ensure an FTM concentration of less than $3 \log _{10}$ spores/L.

The aim of this study of Dutch farms was to determine the effect of different aspects of farm management on $\mathrm{BAB}$ spore concentrations in FTM using a year-long survey. In addition, the results of the survey were used to validate the control strategy derived from model simulations.

\section{MATERIALS AND METHODS}

\section{Selection of Farms}

In total, 24 farms spread across the Netherlands were selected for the survey. The farms were selected using historical data from the Netherlands Milk Control Station (Zutphen, the Netherlands). The Milk Control Station performs monthly tests for the presence of $\mathrm{BAB}$ spores in FTM. To select the 24 survey farms, 270 farms spread across the Netherlands were divided into 3 groups. The first group (group A) consisted of farms where none of the 12 measurements, performed in the framework of the milk quality payment system in 2004, resulted in a double-positive test result for the presence of BAB spores in FTM (i.e., two 0.1-mL tubes of FTM tested positive for spores of $\mathrm{BAB}$ ). The second group (group B) consisted of farms with 1 or 2 double-positive test results in 2004. The third group (group C) consisted of farms with more than 2 double-positive test results in 2004. Out of groups A, B, and C, respectively, 10, 9, and 5 farms were selected randomly for the survey. In the total population of Dutch farms, $92.1 \%$ of the farms belonged to group A, 7.5\% of the farms belonged to group B, and $0.3 \%$ of the farms belonged to group C.

\section{Sample Collection}

Samples were collected between January and December 2005. Each farm was visited 6 times at intervals of 8 wk. At each visit, in addition to sample collection, a questionnaire was answered to collect actual farm management data. The questionnaire contained questions related to the feed ration fed to the cows, housing conditions, and milking practices. The questionnaire was completed by the researcher visiting the farm.

The following sample types were collected: FTM (every visit), feces from the barn (when cows were housed half a day or all day), feces from the pasture (when cows were grazing all day), bedding material from the barn (when cows were housed half a day or all day), soil (when cows were at pasture half a day or all day), and mixed silage in the barn (every visit when appro- priate). No samples of individual grass and corn silage were taken because earlier studies had shown that a sample of the mixed silage offered to the cows is a better indicator of the microbial quality of the silage fed (Vissers et al., 2007). All but the FTM sample were composite samples. Each composite sample consisted of 10 randomly collected subsamples that were mixed on location. Samples were stored at 4 to $6^{\circ} \mathrm{C}$ until microbial analysis within $24 \mathrm{~h}$ after sampling.

\section{Microbial Analyses}

The concentrations of BAB spores in FTM, feces, bedding material, mixed silage, and soil were determined by a most probable number method according to the Dutch Standard (NEN-ISO-6877, 1994). Feces, bedding, soil, silage, and feed extracts were prepared by adding $90 \mathrm{~mL}$ of peptone physiological salt solution (PPS; $1 \mathrm{~g}$ of bacteriological peptone and $8.5 \mathrm{~g}$ of sodium chloride/L) to $10 \mathrm{~g}$ of sample and homogenizing for $2 \mathrm{~min}$ in a laboratory blender (Stomacher, Seward Medical, London, UK). Decimal dilution series of extracts were prepared in PPS. A $0.1-\mathrm{mL}$ volume of diluted extract was added to tubes containing $10 \mathrm{~mL}$ of sterilized milk supplemented with glucose $(0.5 \%)$ and lactic acid $(0.18 \%)$. The tubes were heated for $5 \mathrm{~min}$ at $80^{\circ} \mathrm{C}$ to inactivate vegetative cells and to trigger the germination of spores, then sealed with paraffin and incubated for $4 \mathrm{~d}$ at $37^{\circ} \mathrm{C}$. A tube scored positive if, after incubation, gas formation was visible. The detection limit was 30 spores/L for FTM and 300 spores/g for feces, bedding, mixed silage, and soil.

\section{Statistical Analyses}

Statistical calculations were performed using Statistica (StatSoft Inc., Tulsa, OK) and Microsoft Excel (Microsoft, Redmond, WA). To perform statistical analyses, samples containing BAB spore concentrations below the detection limit were assigned a concentration equaling half the detection limit. All statistical analyses were performed on $\log _{10}$ transformed data.

Student's $t$-tests were used to determine significant differences between farms and spore concentrations in different carriers (i.e., feces, bedding material, mixed silage, and soil) and to detect possible effects of farm management practices on $\mathrm{BAB}$ spore concentrations in FTM. The Fisher exact test was used to determine whether high concentrations occurred more frequently in a specific carrier or group.

\section{RESULTS}

\section{$B A B$ Spore Concentration in FTM and the Farm Environment}

Table 1 gives an overview of BAB spore concentrations measured in FTM and carriers of BAB spores in 
Table 1. Butyric acid bacteria (BAB) spore concentrations measured in farm tank milk and in environmental carriers

\begin{tabular}{|c|c|c|c|c|c|}
\hline \multirow[b]{2}{*}{ Item } & \multirow{2}{*}{$\begin{array}{l}\text { Number } \\
\text { of samples }\end{array}$} & \multicolumn{3}{|c|}{ BAB spores $\left(\log _{10} \text { spores } / \mathrm{L} \text { or } \log _{10} \text { spores } / \mathrm{g}\right)^{1}$} & \multirow{2}{*}{$\begin{array}{l}\text { Fraction of } \\
\text { samples with a } \\
\text { critically high } \\
\text { concentration }\end{array}$} \\
\hline & & Mean & SEM & Range & \\
\hline Farm tank milk & 142 & 2.7 & 0.06 & $<1.5-4.2$ & 0.33 \\
\hline Feces & 141 & 4.7 & 0.07 & $<1.5-7.0$ & 0.33 \\
\hline Bedding material & 113 & 4.5 & 0.07 & $<1.5-6.0$ & 0.20 \\
\hline Mixed silage & 122 & 4.2 & 0.09 & $<1.5-6.0$ & 0.18 \\
\hline Soil & 59 & 4.2 & 0.06 & $3.2-4.9$ & 0 \\
\hline
\end{tabular}

${ }^{1} \log _{10}$ spores/L for farm tank milk; $\log _{10}$ spores/g for feces, bedding material, mixed silage, and soil.

${ }^{2}$ The fraction of samples with a concentration greater than $3 \log _{10}$ spores/L (milk), or the fraction of samples with a concentration greater than $5 \log _{10}$ spores/g (feces, bedding, silage, and soil).

the farm environment (environmental carriers) on all 24 farms during the survey. The average BAB spore concentration in FTM was close to the MSL (3 $\log _{10}$ spores/L). In $33 \%$ of the FTM, the MSL was exceeded. Also in feces, bedding material, and mixed silage, high concentrations (above $5 \log _{10}$ spores/g) were frequently detected. Spore concentrations in feces and bedding material did not statistically differ $(P>0.2)$. Spore concentrations in feces were higher than those in the mixed silage $(P<0.01)$, most likely because of a concentration effect (Te Giffel, 2002). The BAB spore concentrations in soil varied much less than the concentrations in the other environmental carriers and never exceeded $5 \log _{10}$ spores/g. No relationship between soil type (e.g., clay, sand, and peat) and $\mathrm{BAB}$ spore concentration was found $(P>0.2)$.

\section{Comparison of Farms}

The results were evaluated in 2 ways. First, the farms were grouped based on the results of the BAB test in the milk payment system of 2004 (historical grouping, Table 2). Second, farms were grouped based on the average $\mathrm{BAB}$ spore concentration detected in FTM per farm in the survey (survey grouping, Table 2). Based on the historical grouping, group A farms had lower spore concentrations in FTM than group B farms, and group B farms had lower spore concentrations than group $\mathrm{C}$ farms. In the survey grouping (Table 2) the low group represents the 6 farms with the lowest average $\mathrm{BAB}$ spore concentrations in FTM, the high group represents the 6 farms with the highest average $\mathrm{BAB}$ spore concentration in FTM, and the medium group represents the remaining 12 farms. Average BAB spore concentrations in FTM per farm ranged from 1.8 to 3.4 $\log _{10}$ spores/L.

There was no distinct relationship between the historical grouping and the grouping based on survey data. Of the 6 farms with the lowest average BAB spore concentrations in FTM in the survey, 5 farms originated from group $\mathrm{A}$ and one from group $\mathrm{C}$ of the historical grouping. The farms with the highest average FTM concentrations in the survey originated from groups A (1 farm), B (3 farms), and C (2 farms) of the historical grouping.

Clear relationships were found after grouping based on the survey data (Table 2). The 6 farms that fed mixed silage with the lowest average spore concentration (3.4 $\log _{10}$ spores/g) also produced FTM with the lowest average concentrations $\left(2.1 \log _{10}\right.$ spores/g). Conversely, the 6 farms with the highest FTM concentration (3.2 $\log _{10}$ spores/g) also fed silage with the highest average concentration (4.7 $\log _{10}$ spores/g). These concentrations were around the critical levels defined for FTM and silage by Vissers et al. (2006). Survey data in Table 2 also indicated that the relationship between average concentrations in mixed silage, feces, and FTM was almost linear on a $\log _{10}$ scale because the absolute differences observed at the low, medium, and high farms were similar for these 3 carriers (i.e., $\sim 1.1 \log _{10}$ difference between low and high and $0.7 \log _{10}$ difference between low and medium). Historical grouping (Table 2) gave less clear relations than grouping based on the survey data. However, the farms that performed best based on the historical data (group A) also had the lowest average BAB spore concentrations in mixed silage and FTM.

On all farms in the survey, substantial fluctuations were observed in BAB spore concentrations in FTM and environmental carriers. On only 4 farms (3 from the low group and 1 from the medium group) was the $\mathrm{BAB}$ spore concentration in FTM consistently below the MSL. Also in feces, bedding material, and mixed silage, critically high concentrations ( $>5 \log _{10}$ spores/g) were occasionally found on farms with the lowest spore concentration in FTM. For example, the highest BAB spore concentration in feces $\left(7 \log _{10}\right.$ spores/g) was observed on the farm with the third lowest average BAB spore concentration in FTM. At the visit to this farm, the feces sample contained $7 \log _{10}$ spores/g and the $\mathrm{BAB}$ 
spore concentration in FTM was $4.1 \log _{10}$ spores/L. However, critically high $\mathrm{BAB}$ spore concentrations in feces, bedding material, and mixed silage were more frequently observed on the farms with the highest average concentrations in FTM. Nevertheless, all farms except one were able to meet the MLS on at least 2 of the visits. On all farms, the concentration was above the MSL at least once.

\section{Effects of Farm Management}

In addition to the determination of $\mathrm{BAB}$ spore concentrations, data about farm management practices at the participating farms were collected by using a questionnaire. Table 3 gives an overview of farm management practices related to the housing of cows, milking hygiene, and type of silage fed. Statistically significant relationships among the $\mathrm{BAB}$ spore concentrations in FTM were found only for the location of the cows during the summer period and for the presence in the herd of cows preferring to lie down on dirty patches. Therefore, these aspects were analyzed in more detail.

Table 4 shows the BAB spore concentration measured in the winter period and for the different housing situations observed during the summer period. During the winter period, cows were housed $24 \mathrm{~h}$ of the day at $96 \%$ of the farm visits. Table 4 shows that keeping cows 24 $\mathrm{h}$ a day at pasture leads to a reduction of the level of FTM with BAB spores. The observed lower BAB spore concentration in FTM for this situation seems to be related to the lower concentration in feces. The BAB spore concentration in mixed silage did not differ $(P>$ 0.2 ). Further analysis suggested, however, that it was probably not the location of the cows that was important but whether the cows were fed silage or not. The questionnaire revealed that in $66 \%$ of the cases in which cows were grazing all day, the diet of fresh grass was supplemented with silage. In these cases, cows were offered silage in the barn before milking. When the diet of grazing cows was not supplemented with silage, the BAB spore concentration in FTM never exceeded 1.6 $\log _{10}$ spores/L (5 samples), whereas when silage was fed to cows grazing all day, the BAB spore concentration in FTM ranged from $<1.5$ to $3.7 \log _{10}$ spores/L (9 samples).

Another farm management factor that was studied in detail was the presence in the herd of cows preferring to lie down on dirty patches. Teats of these cows are generally more heavily contaminated with feces and thus more spores are transmitted to milk. Indeed, statistical analysis of the data indicated that when cows preferring to lie down on dirty patches were absent from the herd, BAB spore concentrations in milk were lower $\left(0.5 \log _{10}\right.$ spores/L). However, further analysis of 
Table 3. Farm management practices at the farms in the survey

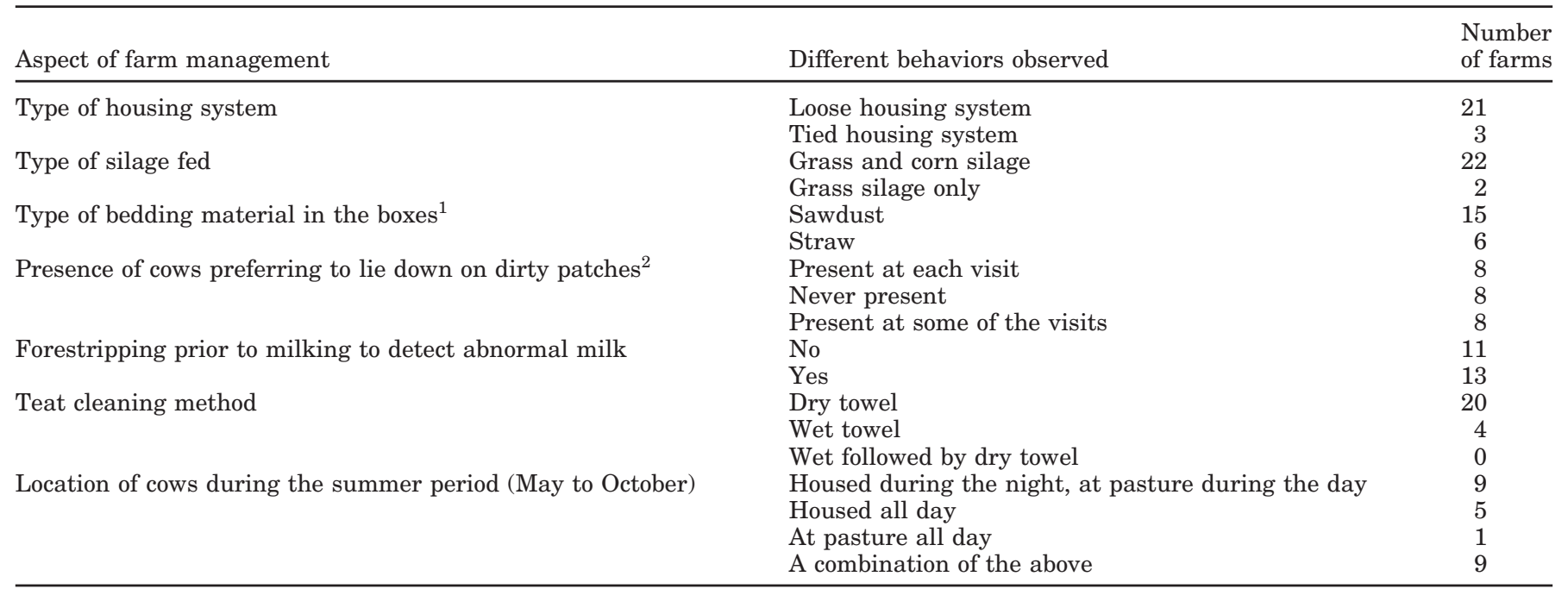

\footnotetext{
${ }^{1}$ No bedding material used at farms with tied-housing system.

${ }^{2}$ Some cows in a herd prefer to lie down on dirty patches and not in clean boxes. Teats of cows that lie down on dirty patches are generally more heavily contaminated than teats of other cows.
}

the data demonstrated that spore concentrations in feces and mixed silage at the farms with cows preferring to lie down on dirty patches were also $0.5 \log _{10}$ spores/ $\mathrm{g}$ higher. It is therefore more likely that the observed difference in FTM was due to differences in spore concentration in the mixed silage offered to the cows and not to the absence or presence of cows preferring to lie down in dirty patches in the herd.

\section{Critical Concentrations in Feces, Bedding, and Mixed Silage}

Figures 1 and 2 show the fraction of FTM samples with a $\mathrm{BAB}$ spore concentration below and above the MSL in relation to BAB spore concentrations in feces and mixed silage. Figure 1 shows that BAB spore concentrations in feces above $5 \log _{10}$ spores/g were critical with respect to the production of FTM with fewer spores than the MSL. When feces contained more than $5 \log _{10}$ spores/g, almost $60 \%$ of the FTM exceed the MSL. On the other hand, when feces contained less than $4 \log _{10}$ spores/g, none of the FTM exceeded the criterion. These results suggest that farmers should try to take measures that result in a $\mathrm{BAB}$ spore concentration in feces of less than $4 \log _{10}$ spores/g.

The $\mathrm{BAB}$ spore concentration in feces relates to the BAB spore concentration in mixed silage. Figure 2 shows that also in mixed silage a critical concentration can be distinguished. A BAB spore concentration of greater than $5 \log _{10}$ spores/g in mixed silage should be prevented. When mixed silage contained more than 5 $\log _{10}$ spores, almost $70 \%$ of the FTM samples contained more spores than the MSL. Conversely, when the silage contained less than $3 \log _{10}$ spores/g, only about $13 \%$ of the FTM contained more spores than the MSL of $3 \log _{10}$ spores/L.

\section{DISCUSSION}

\section{A Control Strategy}

The data presented in this paper confirm conclusions drawn in a modeling study concerning control of BAB spore concentrations in FTM (Vissers et al., 2006). In that study, a model was developed that described the transmission of BAB spores from mixed silage, other feeds, and soil via feces to FTM as a function of farm management factors. In the modeling study, we concluded that to control the level of BAB spores in FTM, it was by far the most important to control the concentration of $\mathrm{BAB}$ spores in the silage fed to the cows. Other control measures were considered to have only a marginal impact.

The survey in this study confirmed that control of the $\mathrm{BAB}$ spore concentration in silage was by far the most important option to control the $\mathrm{BAB}$ spore concentration in FTM. Other measures that were presumed important, such as teat cleaning (Stadhouders and Jörgenson, 1990), were much less important. In line with the model of Vissers et al. (2006), a more or less linear relation was found among $\mathrm{BAB}$ spore concentrations in mixed silage offered to the cows, feces, and FTM (Table 2 ). On the rare occasions (5 of the 144 visits) when no grass silage or corn silage was fed to the cows, the spore concentration in FTM never exceeded $1.6 \log _{10}$ spores/L. 


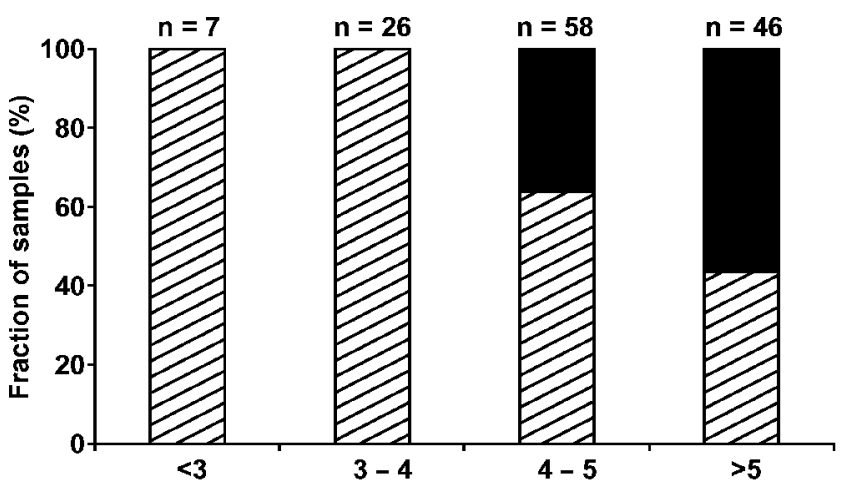

Butyric acid bacteria spore concentration in feces $\left(\log _{10} \mathrm{cfu} / \mathrm{g}\right)$

Figure 1. Fraction of farm tank milk samples with concentrations above (solid bars) and below (hatched bars) the maximum spore limit of $3 \log _{10}$ spores/L as a function of the butyric acid bacteria spore concentration in feces.

The most efficient way to control the BAB spore concentration in FTM was shown to be by controlling the $\mathrm{BAB}$ spore concentration in mixed silage. Farmers that produced milk with the lowest average BAB spore concentrations in FTM $\left(2.1 \log _{10}\right.$ spores/L) also fed mixed silage to the cows with the lowest average spore concentrations (3.4 $\log _{10}$ spores/g). Conversely, farmers with the highest average BAB spore concentrations in FTM (3.2 $\log _{10}$ spores/L) fed mixed silage with the highest average concentrations (4.7 $\log _{10}$ spores/g). Apart from silage feed and silage quality, no relevant relations with other aspects of farm management were detected.

In the modeling study by Vissers et al. (2006), it was postulated that to consistently produce FTM meeting the MSL, farmers should aim for a concentration of $\mathrm{BAB}$ spores in the silage fed of below $3 \log _{10}$ spores/g (in combination with a moderate level of teat hygiene)

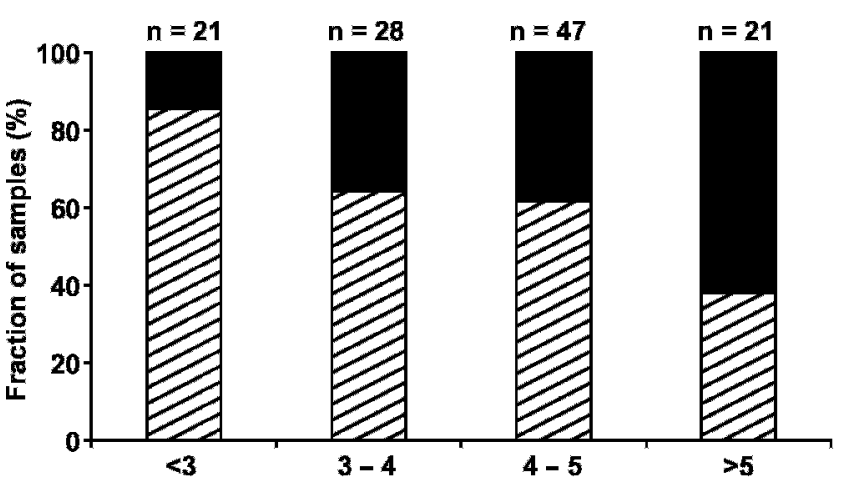

Butyric acid bacteria spore concentration in silage $\left(\log _{10} \mathrm{cfu} / \mathrm{g}\right)$

Figure 2. Fraction of farm tank milk samples with concentrations above (solid bars) and below (hatched bars) the maximum spore limit of $3 \log _{10}$ spores/L as a function of the butyric acid bacteria spore concentration in mixed silage. 
and should prevent concentrations of more than $5 \log _{10}$ spores/g (Vissers et al., 2006). Figures 1 and 2 confirm that these concentrations are critical for control. When the mixed silage offered to the cows contained more than $5 \log _{10}$ spores/g, the majority of the FTM samples exceeded the MSL. On the other hand, when the silage fed contained fewer than $3 \log _{10}$ spores/g of FTM, only a minority of the samples (13\%) exceeded the MSL. At concentrations in mixed silage between 3 and $5 \log _{10}$, the number of FTM samples with a BAB spore concentration above and below the MSL was similar. At these concentrations in mixed silage, presumably the level of fecal contamination of the teat exterior plays a role, as also stated in the modeling study. The agreement between the survey results and results obtained in a modeling study emphasizes the usefulness of the modeling approach for identifying measures to control the microbial contamination of FTM.

\section{Incident Management}

In achieving and maintaining $\mathrm{BAB}$ spore concentrations of less than $3 \log _{10}$ spores/g in silage fed to cows, the heterogeneous distribution of BAB spores in grass and corn silage is a difficulty. A number of studies have shown that BAB spore concentrations in grass and corn silage can be highly elevated locally (up to $>7 \log _{10}$ spores/g), whereas the concentration in the bulk of the silage is low (less than $3 \log _{10}$ spores/g; Jonsson, 1991; Driehuis and Te Giffel, 2005; Vissers et al., 2007). When such local spots with high BAB spore concentrations are mixed with the bulk of the silage and other silage, the average $\mathrm{BAB}$ spore concentration in the mixed silage fed to cows increases significantly, as was confirmed in a recent study (Vissers et al., 2007). The heterogeneous distribution of $\mathrm{BAB}$ spores in silage may explain why even farms with a low average $\mathrm{BAB}$ spore concentration in FTM occasionally produce FTM with a BAB spore concentration above the MSL (Table 2). As such, efficient farm management with respect to control of the contamination of FTM with BAB spores probably depends on the ability of farmers to minimize the incidence of elevated $\mathrm{BAB}$ spore concentrations $(>5$ $\log _{10}$ spores/g) in the mixed silage fed to cows in the barn.

\section{Control of BAB Spores in Mixed Silage}

To ensure that the mixed silage fed contains fewer than $3 \log _{10}$ spores/g, it is important to limit the initial contamination of silage with $\mathrm{BAB}$ spores and to prevent the growth of $\mathrm{BAB}$ during ensilage, storage, and feedout. Silage is initially contaminated with $\mathrm{BAB}$ spores as soil is enclosed during harvesting (Pahlow et al.,
2003). The BAB spore concentrations measured in soil (Table 1) indicate that an initial contamination level of less than 3 spores/g of silage can be secured when less than $1 \%$ of soil is enclosed. To prevent the growth of $\mathrm{BAB}$, it is first important to produce an anaerobically stable silage by ensuring a fast and sufficiently deep decline of the $\mathrm{pH}$ by lactic acid fermentation (Weissbach, 1996; Pahlow et al., 2003). Second, penetration of oxygen into the silage during storage and feed-out should be prevented. Penetration of oxygen is the most likely cause of locally increased BAB spore concentrations in silage (Jonsson, 1991; Vissers et al., 2007). The presence of oxygen in silage enables yeasts to grow and consume the organic acids. As a consequence, $\mathrm{pH}$ rises locally and $\mathrm{BAB}$ may start to proliferate, resulting in small pockets with a very high $\mathrm{BAB}$ spore concentration. Adequate sealing of silage and a high silage density limit the penetration of oxygen (Parsons, 1991; McGechan and Williams, 1994).

\section{Late-Blowing in Summer}

Traditionally, late-blowing of cheeses was exclusively associated with milk produced in the winter period. In the Dutch milk quality payment system, FTM was therefore initially tested for $\mathrm{BAB}$ spores during the winter period only. In recent years, however, incidents of late-blowing in cheese have occurred more often during the summer, suggesting that also during the summer period the FTM has contained significant concentrations of BAB spores. As a reaction, since 2004 FTM has been tested for BAB spores all year round. The results shown in Table 4 concerning the BAB spore concentrations in FTM in summer and winter confirm that this change in the milk payment system was justified. The survey presented in this paper clearly demonstrates that the increased frequency of late-blowing during summer is most likely due to changed feeding and housing patterns in the summer. In the past in the Netherlands, cows were fed silage and housed all day only during the winter period. In summertime, cows were grazing all day and no silage was fed. Nowadays in the summer period, cows are generally in the barn for at least half of the day (Table 3), but more importantly, silage is fed all year round, even when cows graze all day.

\section{CONCLUSIONS}

To ensure BAB spore concentrations in FTM of less than the MSL of $3 \log _{10}$ spores/L, farmers should aim for an average $\mathrm{BAB}$ spore concentration in the mixed silage fed of less than $3 \log _{10}$ spores/g and prevent concentrations of more than $5 \log _{10}$ spores/g. Other aspects 
of farm management did not affect the observed spore concentrations in FTM. Efficient control of the BAB spore concentrations in FTM of less than $3 \log _{10}$ spores/ $\mathrm{L}$ mainly depends on the ability of farmers to prevent incidents with elevated concentrations in mixed silage fed ( $>5 \log _{10}$ spores/g). The results of the survey were in agreement with a previous modeling study of the contamination of FTM by BAB spores, emphasizing the usefulness of a modeling approach to identify measures to control the microbial contamination of FTM.

\section{REFERENCES}

Bergère, J. L., P. Gouet, J. Hermier, and G. Mocquot. 1968. Les Clostridium du groupe butyrique dans les produit laitiers. Ann. Inst. Pasteur (Paris) 19:41-54.

Driehuis, F., and M. C. Te Giffel. 2005. Butyric acid bacteria spores in whole crop maize silage. Page 271 in Silage Production and Utilisation, 14th Int. Silage Conf., Belfast, UK. D. I. H. Jones, R. Dewhurst, R. Merry, and P. M. Haigh, ed.

Jonsson, A. 1991. Growth of Clostridium tyrobutyricum during fermentation and aerobic deterioration of grass silage. J. Sci. Food Agric. 54:557-568.

Klijn, N., F. F. J. Nieuwenhof, J. D. Hoolwerf, C. B. v. d. Waals, and A. H. Weerkamp. 1995. Identification of Clostridium tyrobutyricum as the causative agent of late blowing in cheese by speciesspecific PCR amplification. Appl. Environ. Microbiol. 61:29192924.

McGechan, M. B., and A. G. Williams. 1994. A model of air infiltration losses during silage storage. J. Agric. Eng. Res. 57:237-249.
NEN-ISO. 1994. Milk and milk products-Detection of spores of butyric acid bacteria and determination of the content of spores of butyric acid bacteria. Vol. 6877:1-12. Netherlands Normalisation Institute (NEN-ISO), Delft, the Netherlands.

Pahlow, G., R. E. Muck, F. Driehuis, S. J. W. H. Oude Elferink, and S. F. Spoelstra. 2003. Microbiology of ensiling. Pages 31-93 in Silage Science and Technology. L. Al-Amoodi, ed. American Society of Agronomy, Crop Science Society of America, and Soil Science Society of America, Madison, WI.

Parsons, D. J. 1991. Modelling gas flow in a silage clamp after opening. J. Agric. Eng. Res. 50:209-218.

Stadhouders, J. 1990. Prevention of butyric acid fermentation by the use of nitrate. Bull. Int. Dairy Fed. 251:40-46.

Stadhouders, J., and K. Jørgensen. 1990. Prevention of the contamination of raw milk by a hygienic milk production. Bull. Int. Dairy Fed. 251:32-36.

Te Giffel, M. C., A. Wagendorp, A. Herrewegh, and F. Driehuis. 2002. Bacterial spores in silage and raw milk. Antonie van Leewenhoek 81:625-630.

Vissers, M. M. M., F. Driehuis, M. C. Te Giffel, P. De Jong, and J. M. G. Lankveld. 2006. Improving farm management by modeling the contamination of farm tank milk with butyric acid bacteria. J. Dairy Sci. 89:850-858.

Vissers, M. M. M., F. Driehuis, M. C. Te Giffel, P. De Jong, and J. M. G. Lankveld. 2007. Concentrations of butyric acid bacteria spores in silage and relationships with aerobic deterioration. J. Dairy Sci. 90:928-936.

Waes, G., A. v. Heddeghem, and A. Van Heddeghem. 1990. Prevention of butyric acid fermentation by bacterial centrifugation of the cheese milk. Bull. Int. Dairy Fed. 251:47-50.

Weissbach, F. 1996. New developments in crop conservation. Pages 11-25 in XIth Int. Silage Conf., Aberystwyth, UK. R. S. Park and M. D. Stronge, ed. 